\title{
Thermal Properties of Conduction Current and Carrier Behaviors in Organic Electroluminescent Device
}

\author{
Masahiro Minagawa Student Member (Niigata University, m-mina@nippon-seiki.co.jp) \\ Kazunari Shinbo Member (Niigata University, kshinbo@eng.niigata-u.ac.jp) \\ Keizo KatoＳenior Member (Niigata University, keikato@eng.niigata-u.ac.jp) \\ Futao Kaneko Senior Member (Niigata University, fkaneko@eng.niigata-u.ac.jp)
}

Keywords : organic EL device, thermal property, carrier injection, carrier conduction, space-charge-limited current

Organic electroluminescent devices (OLEDs) were fabricated using a vacuum evaporation method of N,N'-diphenyl-N,N'bis(3-methylphenyl) 1- 1'biphenyl- 4,4'-diamine (TPD) and tris(8-hydroxyquinoline) aluminum (Alq) on Indium Tin Oxide (ITO). Thermal dependences of electrical properties have been investigated for devices with single organic layer of TPD or Alq, and OLED with TPD and Alq. The study of temperature dependence of OLEDs is important, since OLEDs will be used in outdoor or in automobile having a large temperature differences.

Figure 1 shows structures of the OLED and single organic layer devices. OLED had the structure of ITO/TPD $(60 \mathrm{~nm}) / \mathrm{Alq}(60$ $\mathrm{nm}) / \mathrm{LiF}(0.5 \mathrm{~nm}) / \mathrm{Al}$. Single organic layer devices of ITO/TPD(30, $60,120 \mathrm{~nm}) / \mathrm{Al}$ and $\mathrm{Al} / \mathrm{Alq}(30,60,120 \mathrm{~nm}) / \mathrm{LiF} / \mathrm{Al}$ structures were fabricated for investigation of hole and electron conduction in TPD and Alq films, respectively.

Figure 2 shows the current density-voltage $(J-V)$ properties in single carrier dominant device (hole), ITO/TPD/Al. The thickness dependence at $300 \mathrm{~K}$ is shown and the property indicated space-charge-limited current (SCLC), $J \propto V^{2}$, in large current region. Schottky injection was also estimated in small current region at $300 \mathrm{~K}$.

Figures 3 shows the $J-V$ properties at $300 \mathrm{~K}$ in single carrier dominant device (electron) $\mathrm{Al} / \mathrm{Alq} / \mathrm{LiF} / \mathrm{Al}$. The thickness dependence is shown and the conduction current is considered to be due to SCLC with traps $\left(J \propto V^{m+1}\right)$. The current can be obsereved when traps are distributed under conduction band with $\exp \left(\left(E-E_{c}\right) / k T_{t}\right)$ relationship. $T_{t}$ is a temperature parameter which shows trap distribution and energy parameter $E_{t}$ can be defined as $E_{t}=k T_{t}$. $E_{t}$ was estimated to be $0.147 \mathrm{eV}$ from temperature dependence of $J-V$ properties. The activation energy of the conduction current was also obtained to be $0.150 \mathrm{eV}$ from the

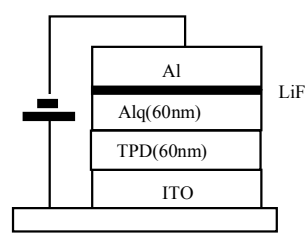

(a) OLED

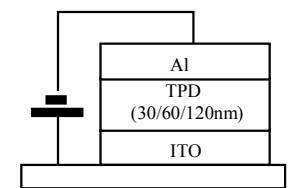

(b) Hole dominant device

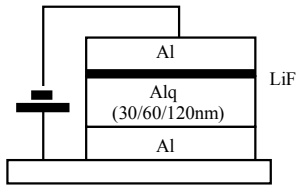

(c) Electron dominant device
Fig. 1. Device structures of organic electroluminescent device and single carrier dominant devices

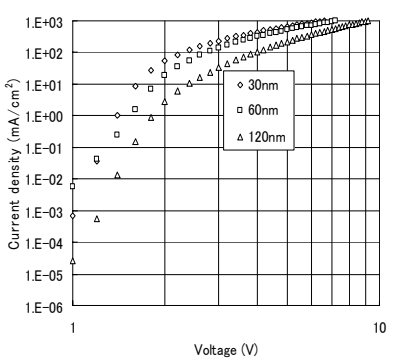

Fig. 2. $J-V$ properties at $300 \mathrm{~K}$ in single carrier devices (hole) with different thicknesses

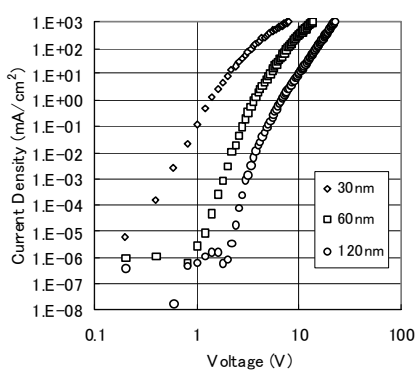

Fig. 3. $J-V$ properties at $300 \mathrm{~K}$ in single carrier devices (electron) with different thicknesses

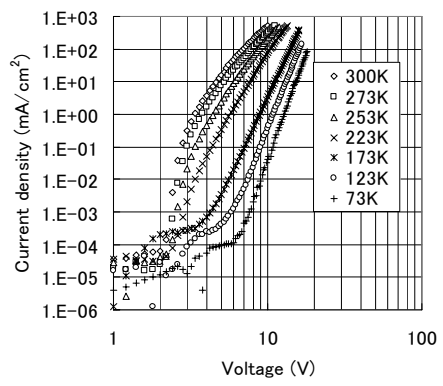

Fig. 4. $J-V$ properties in OLED at various temperatures

temperature dependence of conduction current.

Figure 4 shows $J-V$ properties in OLED. The resistivity in Alq is larger than that of TPD, hence the current is considered to be dominated in Alq. The $J-V$ properties are estimated to be SCLC with traps $\left(J \propto V^{m+1}\right)$ at wide temperature region. However, the conduction mechanism is complicated because holes and electrons are injected from ITO and $\mathrm{Al}$ elecrodes and recombination process is involved.

It is necessary to investigate a carrier injection process and trap distribution in organic film in detail. 


\begin{abstract}
有機 $\mathrm{EL}$ 素子における電気伝導の温度特性とキャリア挙動

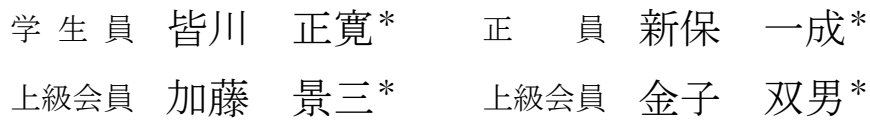

\section{Thermal Properties of Conduction Current and Carrier Behaviors in Organic Electroluminescent Device}

Masahiro Minagawa*, Student Member, Kazunari Shinbo*, Member, Keizo Kato*, Senior Member,

Futao Kaneko*, Senior Member

Organic Electroluminescent device (OLED) was fabricated using a vacuum evaporation method and thermal properties were investigated. The OLED has an Indium Tin Oxide (ITO)/ N,N'-diphenyl-N,N'bis(3-methylphenyl) 1- 1'biphenyl- 4,4'-diamine (TPD)/ tris- (8-hydroxyquinoline) aluminum (Alq)/ Lithium fluoride $(\mathrm{LiF}) /$ aluminum (Al) structure. An electron dominant device of an $\mathrm{Al} / \mathrm{Alq} / \mathrm{LiF} / \mathrm{Al}$ structure, or a hole dominant device of an ITO/ TPD/ Al structure was also fabricated in order to study the carrier behavior in the OLEDs. The current density vs. voltage $(J-V)$ properties with various thickness of organic layers were investigated in the both electron and hole dominant devices, and the thermal dependence of $J$ - $V$ properties was observed in the devices. At room temperature, conductions in large current region were considered to be due to space-charge-limited current for all the devices. Especially, for the $\mathrm{Al} / \mathrm{Alq} / \mathrm{LiF} / \mathrm{Al}$ device and the OLED, J $\propto V^{m+1}$ relationships were observed across wide current region. At low temperature, tunnel currents were estimated for the ITO/TPD/Al device. For the Al/ Alq/ LiF/ Al device and the OLED, $J \propto V^{m+1}$ relationships were observed across wide current region at low temperature.
\end{abstract}

論 文

キーワード：有機 EL 素子，温度特性，電荷注入，電荷伝導，空間電荷制限電流

Keywords : organic EL device, thermal property, carrier injection, carrier conduction, space-charge-limited current

\section{1. まえがき}

有機電界発光 $(\mathrm{EL})$ 素子は 1997 年に初めて製品化され て以来様々な研究機関で盛んに検討され，今日までに家電 製品，モバイル端末さらには車載用オーディオ，計器など のデジタルディスプレイとして数多く採用されている。デ イスプレイの仕様もモノカラー (緑, 青), エリアカラー, マルチカラーが開発され，さらに近年では白色モノカラー, フルカラーと着実に進化を続けている。またこれに伴い有 機 EL 素子の性能も有機材料や成膜プロセスの改良, 封止技 術の開発などにより, コダック社による 2 層型有機 $\mathrm{EL}$ 素子 の発表から 20 年足らずの間に飛躍的に向上した(1) (8)。

一方で, 車載向け製品に有機 EL 素子を適用する場合など では, 携帯電話やオーディオ機器などのディスプレイに比 ベ環境温度が著しく変化する条件下での使用が想定される

\footnotetext{
新潟大学大学院自然科学研究科

T 950-2181 新潟市西区五十嵐 2-8050

Graduate School of Science and Technology, Niigata University

2-8050, Ikarashi, Nishi-ku, Niigata 950-2181
}

ため, 温度に対する有機 EL 素子の安定性を高めることは重 要な技術課題となっている。

有機 EL 素子は電流駆動デバイスである。したがって輝度 や発光効率などの諸特性は電導電流に大きく依存する。こ のため周辺温度に対する電導電流の温度依存性を制御する ことは, 温度に対する有機 EL 素子の安定性を高める上で重 要と考えられる。そこで我々は, 有機 EL 素子における温度 特性についてより詳細な知見を得るため, 2 層型有機 EL 素 子における電気伝導の温度特性を詳細に調べた。本研究で は有機 EL 素子の電流-電圧特性（以下 $J$ - $V$ 特性）およびそ の温度特性を測定した。また, 有機 EL 素子に用いた有機膜 の単層を電極で挟み込んだ単電荷輸送素子を作製し, その 電気伝導の温度特性から各有機層におけるキャリア輸送お よび注入の挙動と温度依存性の相関を調べた。単電荷輸送 素子の結果および有機 EL 素子の電気伝導特性およびその 温度特性から, 2 層型有機 $\mathrm{EL}$ 素子における電気伝導機構に ついて考察したので報告する。 


\section{2. 試料の作製と実験方法}

図 1 に本実験で作製した有機EL素子および単電荷層デバ イスの構造を示す。下部電極である Indium Tin Oxide (ITO)上にホール輸送層として N,N'-diphenyl-N,N'-bis (3-methyl-phenyl)1-1'biphenyl-4,4'-diamine (TPD), さら に電子輸送発光層として tris- (8-hydroxyquinoline) aluminum (Alq) をそれぞれ 60nm の膜厚となるように真 空蒸着法で成膜した。さらに電子注入層として Lithium fluoride ( $\mathrm{LiF}, 0.5 \mathrm{~nm})$, および陰極として Aluminum (Al, $150 \mathrm{~nm}$ ) を連続で真空蒸着し有機 EL 素子（発光面積 : $4 \mathrm{~mm}^{2}$ ) とした（同図(a)参照)。一方，有機 EL 素子中の各 キャリアの挙動を調べるため図 1(b)，(c)のような単電荷輸 送素子を作製した。単電荷素子は有機材料のイオン化ポテ ンシャルあるいは電子親和力に近い仕事関数をもつ金属を 用いることで，ホールまたは電子を選択的に有機膜へ注入 し輸送することができる素子である。ホールの挙動を知る ために ITO/TPD $(30,60,120 \mathrm{~nm}) / \mathrm{Al}$ の素子を, 電子の挙動 を知るために $\mathrm{Al} / \mathrm{Alq}(30,60,120 \mathrm{~nm}) / \mathrm{LiF} / \mathrm{Al}$ の素子を作製 した。 $\mathrm{LiF}$ 層は $\mathrm{Al}$ 電極から $\mathrm{Alq}$ 層への電子注入を助けるた めのものである。この素子の電気特性および温度依存性を 測定し, 有機 EL 素子における各キャリアの挙動を考察し た。J-V 特性の測定は基板温度を制御できる真空容器内で行 い，半導体パラメータアナライザ（HP-4145B）を用い測定 した。また電導電流の温度特性はデジタルマルチメーター （ADVANTEST, TR-6846）を用いて行った。各測定は ITO 電極に正電圧を印加した場合を順方向とした。

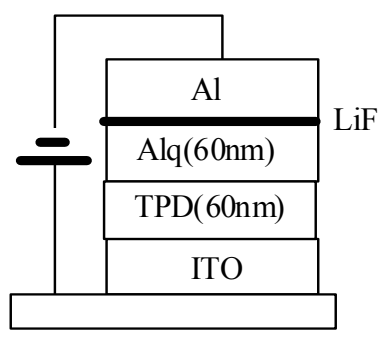

(a) OLED

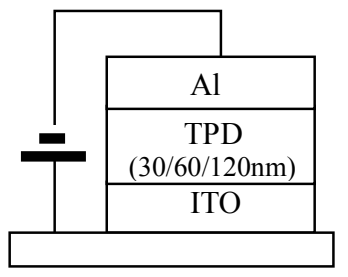

(b) Hole dominant device

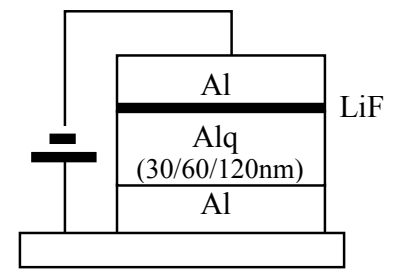

(c) Electron dominant device
図 1 有機 EL 素子および単電荷素子の 素子構造

Fig. 1. Device structures of organic electroluminescent device and single carrier device.

\section{3. 実験結果と考察}

〈3・1〉TPD 膜中のホール伝導図 2 に $\operatorname{ITO} / \operatorname{TPD}(30$, $60,120 \mathrm{~nm}) / \mathrm{Al}$ の単電荷（ホール）素子の $J$ - $V$ 特性を示す。 TPD 層はホール伝導性であることが知られており，ITO は 有機 EL 素子でホール注入側の電極であるため, ITO 側に 正電圧を印加した場合の $J$ - $V$ 特性を調べた。図 2 の $100 \mathrm{~mA} / \mathrm{cm}^{2}$ 以上の電流領域では, 電流が緩やかに増加して いる。図には $J \propto V^{2}$ とした場合の特性も実線で示した。図 のように $100 \mathrm{~mA} / \mathrm{cm}^{2}$ 以上の電流領域ではほぼ $J \propto V^{2}$ 特性 を示しており,この電流領域では空間電荷制限電流 (SCLC) が支配的と考えられた。電極からの電荷注入が制限されな い場合で深さ $E_{t}$ のトラップが存在するときの空間電荷制限 電流 $J_{S C L C}$ は次式で表される。

$$
J_{S C L C}=A \varepsilon \mu \exp \left(-\frac{q E_{t}}{k T}\right) \frac{V^{2}}{\ell^{3}}
$$

ここで $\mathcal{1}$ は誘電率, $\mu$ は移動度であり,$k$ はボルツマン定数, $q$ は電気素量, $T$ は絶対温度, $V$ は印加電圧, $\ell$ は TPD 層 の厚さ， $A$ は定数である。TPD の膜厚増加によって電流は 減少し, $10 \mathrm{~mA} / \mathrm{cm}^{2}$ 付近の電流領域から SCLC 特性が観ら れている。電流は電圧の 2 乗よりも若干大きな值に比例し ており, 直列抵抗の影響が出ているものと考えられる。膜

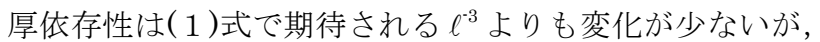
これも直列抵抗の影響によるものと考えられる。例として 電圧で考えた場合, 各膜厚において SCLC 特性が現れ始め る $2 \mathrm{~V}$ での特性を観ると, $30 \mathrm{~nm}$ で $52.9 \mathrm{~mA} / \mathrm{cm}^{2}, 60 \mathrm{~nm}$ で $18.2 \mathrm{~mA} / \mathrm{cm}^{2}, 120 \mathrm{~nm}$ で $2.68 \mathrm{~mA} / \mathrm{cm}^{2}$ となっており, 2 倍の 膜厚増加で電流が $1 / 8$ ずつ小さくる( 1 )式の特性にある程 度近い特性が得られている。なお, 電流が急激に変化して いる約 $10 \mathrm{~mA} / \mathrm{cm}^{2}$ より少ない電流領域の電流は, 注入界面 や TPD 膜のトラップ電荷の効果によると考えられる。

図 3 に ITO/TPD $(60 \mathrm{~nm}) / \mathrm{Al}$ 素子の $J$ - $V$ 特性の温度依存性

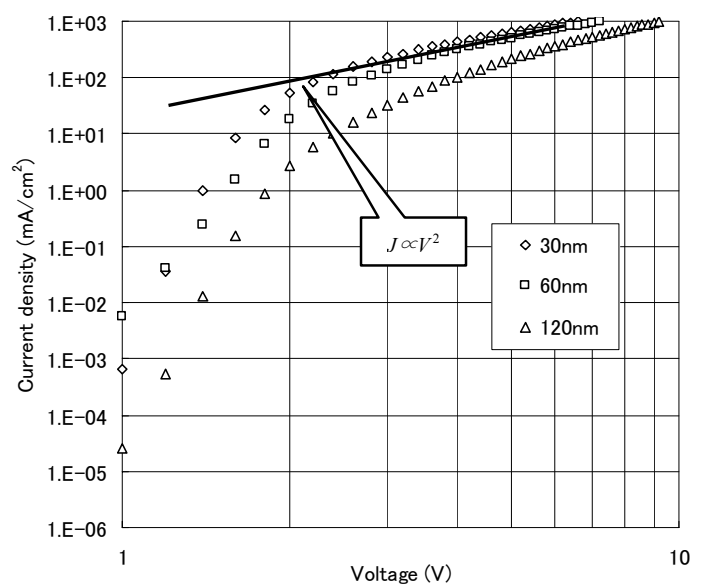

図 2 単電荷 (ホール) 素子の TPD 膜厚と $J-V$ 特性

Fig. 2. $J-V$ properties of TPD films with various thicknesses in single carrier (hole) devices. 


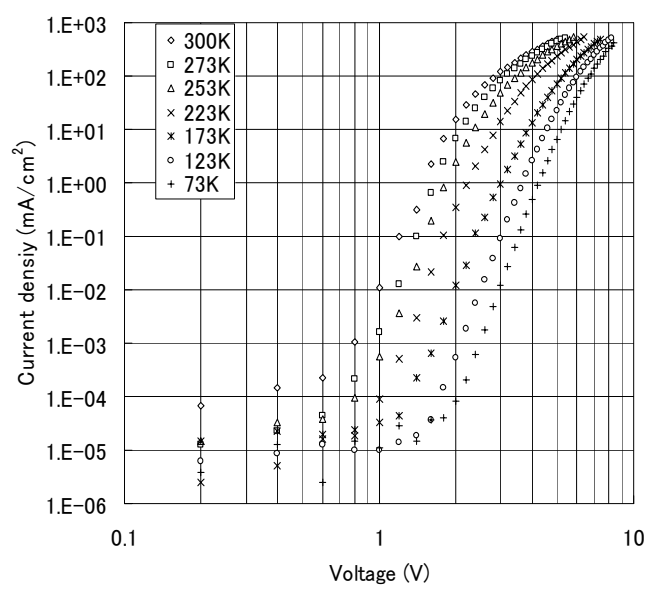

図 3 単電荷（ホール）素子における $J$ - $V$ 特性の 温度依存性

Fig. 3. Thermal dependence of $J$ - $V$ property in a hole carrier device.

を示す。素子の $J-V$ 特性は測定温度により大きく変化し， $200 \mathrm{~K}$ 以下の温度領域では $J_{S C L C} \propto V^{2}$ 特性と大きく異なる 特性が得られた。これは温度が変化することによる注入ホ 一ルの減少や, TPD 中の伝導ホールとトラップされている ホールのバランスが変化したためと考えられた。電極から の注入に対しては，一般に次式の熱活性型のショットキー 注入電流 ${ }^{(9)}$ が考えられる。

$$
J_{s}=B T^{2} \exp \left(-\frac{\phi_{B}}{k T}\right) \exp \left[\frac{1}{k T}\left(\frac{q^{3} F}{4 \pi \varepsilon}\right)^{0.5}\right] \ldots
$$

ここで $B$ はリチャードソン定数， $\varphi_{B}$ は注入障壁高さ，Fは 注入電極界面での電界強度である。

定電圧駆動時（5V:300K では SCLC 特性）の電導電流の 温度特性をアレニウスプロットで図 4 に示す。電導電流は, 約 $150 \mathrm{~K}$ 以上（1/Tが約 $0.0075 \mathrm{~K}^{-1}$ 以下）の温度領域でほぼ 直線的に変化し，150K 以下の温度領域では温度依存性が小 さくなっている。直線で近似される領域における電導電流 の活性化エネルギーは約 $0.081 \mathrm{eV}$ であった。一方, 約 $100 \mathrm{~K}$ 以下 $\left(1 / T=0.01 \mathrm{~K}^{-1}\right.$ 以上) の温度領域では温度依存性がほぼ 観られないことから，(3)式で示されるトンネル型の電荷注 入(10)で律速されていると考えられた。

$$
J_{T}=\left(\frac{q^{3} F^{2} m_{0}}{8 \pi h \phi_{e f f} m^{*}}\right) \exp \left(-\frac{8 \pi\left(2 m^{*}\right)^{0.5} \phi_{e f f}^{1.5}}{3 h q F}\right) .
$$

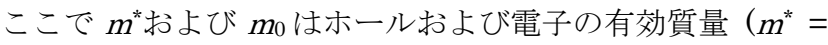
$\left.m_{0}=9.11 \times 10^{-31}[\mathrm{~kg}]\right), h$ はプランク定数， $F$ は注入電極界 面での電界強度であり， $\varphi_{\text {eff }}$ はショットキー効果により低減 された実効的な障壁高さである。また高電界のために注入 電荷に対する実効的な障壁の厚さを $L$ とした。

図 5 に ITO/TPD $(60 \mathrm{~nm}) / \mathrm{Al}$ 素子の $300 \mathrm{~K}$ おび $73 \mathrm{~K}$ にお ける $J$ - $V$ 特性と各電導モデルの計算結果を示す。前述した とおり $300 \mathrm{~K}$ の $100 \mathrm{~mA} / \mathrm{cm}^{2}$ 以上の電流領域は空間電荷制限

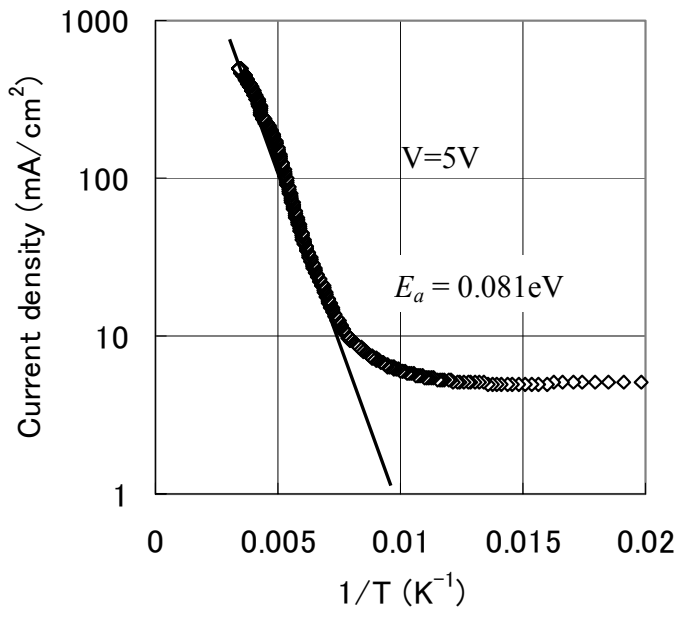

図 4 定電圧駆動時における電導電流の温度特性

Fig. 4. Thermal dependence of conduction current with constant voltage.

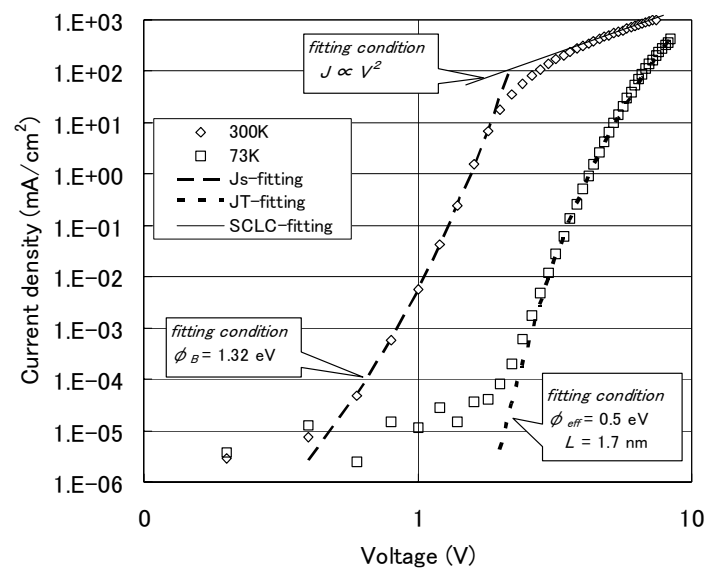

図 5 単電荷（ホール）輸送 TPD 素子の $300 \mathrm{~K}$ および $73 \mathrm{~K}$ における $J$ - $V$ 特性と計算結果

Fig. 5. $J-V$ characteristics at $300 \mathrm{~K}$ and $73 \mathrm{~K}$ for a hole carrier device with a TPD layer and the calculated currents.

電流の $J_{S C L C} \propto V^{2}$ 特性となっている。 $300 \mathrm{~K}$ の $10 \mathrm{~mA} / \mathrm{cm}^{2}$ 以下の電流領域における $J-V$ 特性に対しては, 図のように (2)式の熱活性型の注入電流式をフィッティングすること ができた。一方, $73 \mathrm{~K} の J$ - $V$ 特性に対しては, $0.001 \mathrm{~mA} / \mathrm{cm}^{2}$ から $100 \mathrm{~mA} / \mathrm{cm}^{2}$ の電流領域でトンネル型注入の $(3)$ 式を適 用することができた。熱活性型のホール注入の障壁エネル ギーは $1.32 \mathrm{eV}$ であり，トンネル電流では実効的な障壁高さ $\varphi_{\text {eff }}$ として $0.5 \mathrm{eV}$ が，また実効的な障壁の厚さ $L$ として $1.7 \mathrm{~nm}$ が得られた。これらの值は TPD と電極界面の理想的 なエネルギー帯構造の值と異なる。界面準位の影響などが 考えられるが，現時点では詳細は不明である。

以上のことから $\operatorname{TPD}(60 \mathrm{~nm})$ の単電荷素子に $5 \mathrm{~V}$ 印加し た際の電導特性は， $73 \mathrm{~K}$ 付近ではトンネル現象による電荷 注入が支配的であり，温度が高くなるにつれて熱活性型注 入，さらには空間電荷制限電流が支配的になると考えられ 
た。このように温度により電導律速過程が大きく変化する ため, 電導電流は図 4 のような温度依存性を示したと考え られた。なお, 図 4 で得られた活性化エネルギーは, 上記 の $73 \mathrm{~K}$ から $300 \mathrm{~K}$ における電導律速過程の変化に伴うもの と考えられた。

〈3.2〉 Alq 膜中の電子伝導 図 6 に Al/Alq $(30,60$, $120 \mathrm{~nm}) / \mathrm{LiF} / \mathrm{Al}$ の単電荷（電子）素子の $J-V$ 特性を示す。 電子注入をより優勢にするために $\mathrm{LiF}$ 側の $\mathrm{Al}$ 電極に負電圧 を加えた。 $\mathrm{Alq}$ 層の膜厚の異なる 3 種類の素子において, $100 \mathrm{~mA} / \mathrm{cm}^{2}$ 以上の電流領域で $J \propto V^{2}$ 特性に近い特性を示し ているが，実際の電流は電圧の 2 乗以上の值に比例してい る。Alq 層の膜厚の大きい $60 \mathrm{~nm}$ や $120 \mathrm{~nm}$ の素子では, $1 \mathrm{~mA} / \mathrm{cm}^{2}$ 以上の電流領域でほぼ 3 桁から 4 桁にわたって, $J \propto V^{2}$ 特性よりも急峻に変化する電流が観測されている。一 般に，電流が電圧の 2 乗以上の割合で比例する場合，電流 は有機膜厚を $\ell$ とすると，

$$
J \propto \frac{V^{m+1}}{\ell^{2 m+1}} \quad(\mathrm{~m} \geqq 1)
$$

に従うことが知られている(11)。ここで, $m=1$ の場合が SCLC 特性である。図 6 では, $10 \mathrm{~V}$ 付近で膜厚が 2 倍に増えると 電流は 1 桁以上小さくなっており, (4)式の特性に近い膜厚 依存性を示している。図 2 で TPD 素子が $300 \mathrm{~K}$ において $2 \mathrm{~V}$ 以上の電圧印加で約 $100 \mathrm{~mA} / \mathrm{cm}^{2}$ もの電流が流れるのに対 して, 図 6 の Alq 素子ではより大きな電圧を印加すること で同程度の電流が得られている。このことは Alq 素子が TPD 素子よりも高抵抗で電流が流れにくいことを示してい る。

ここで，(4)式についてもう少し詳しく触れる。(4)式は 膜厚が一定のとき $(5)$ 式のように表され， $m+1$ が図 6 にお ける近似直線の傾きを表している。

$$
J \propto V^{m+1} \quad(\mathrm{~m} \geqq 1)
$$

$m+1$ が 2 よりも大きく, このような $J \propto V^{m+1}$ 特性を示す空 間電荷制限電流はこれまでに詳しく研究されてきてい る(11)。これは $J \propto V^{2}$ 特性を示す電流領域よりも少し低い電

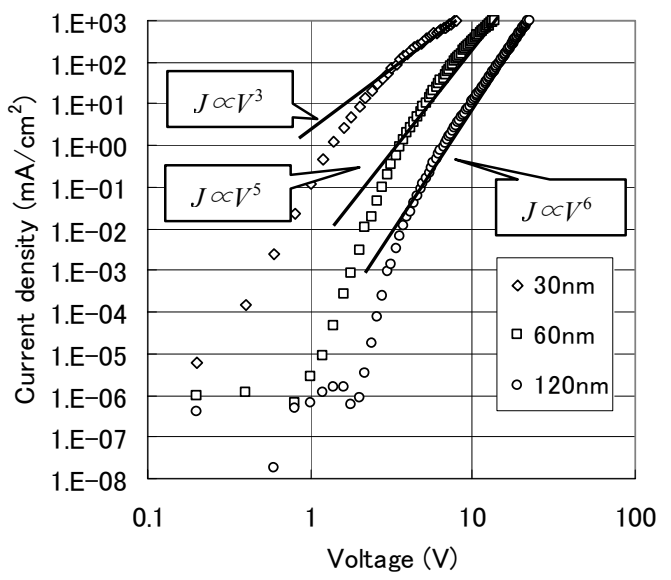

図 6 単電荷（電子）素子の Alq 膜厚と $J$ - $V$ 特性

Fig. 6. $J-V$ properties of Alq films with various thicknesses in single carrier (electron) devices.
流領域で観測されるもので，伝導帯以下のエネルギー $E$ に トラップが

$$
\exp \left(\frac{E-E_{C}}{k T_{t}}\right)
$$

で表されるように指数関数的に分布し，トラップされたキ ヤリアと伝導キャリアが平衡状態を保っている場合に相当 するとされている(11) (14)。ここで $E_{c}$ は伝導帯の底のエネル ギーである。 $T_{t}$ はトラップ分布を決める温度パラメータで, $m=\left(T_{t} / T\right)$ で規格化され, $T_{t}$ すなわち $m$ が大きいとトラッ プのエネルギー分布が緩やかであり， $m$ が小さいと急峻な 分布となる。また, エネルギー分布を明確に示すために $k T_{t}=E_{t}$ としてエネルギーパラメータ $E_{t}$ で表す場合もある。

以上を考慮し, 本研究では厚さ $60 \mathrm{~nm}$ の Alq 層を持つ $\mathrm{Al} / \mathrm{Alq}(60 \mathrm{~nm}) / \mathrm{LiF}(0.5 \mathrm{~nm}) / \mathrm{Al}$ 素子について, $m$ やエネルギ 一分布パラメータ $E_{t}$ について調べた。図 7(a)に定電圧駆動 時 $(10 \mathrm{~V})$ における電導電流の温度特性をアレニウスプロ

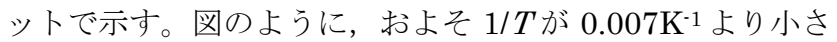
い（150Kよりも高い温度領域）において直線性が得られ,

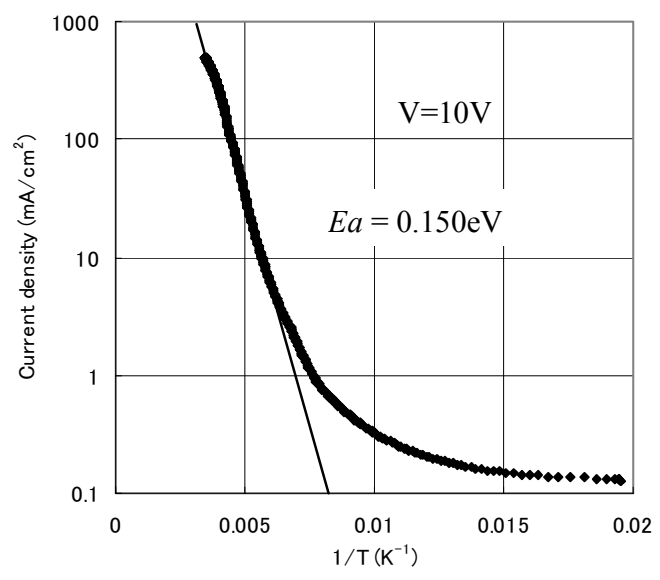

(a) Thermal dependence of conduction current with constant voltage

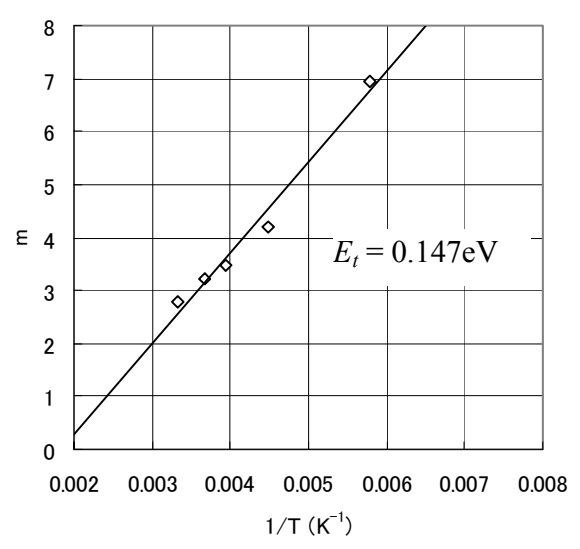

(b) Thermal property of $m$ in Eq. (4)

図 7 単電荷（電子）素子における 電子伝導の温度特性

Fig. 7. Thermal property of electron conduction in single carrier device. 
活性化エネルギーは約 $0.150 \mathrm{eV}$ と見積もられた。また, $150 \mathrm{~K}$ より低い温度領域では明確な直線が得られていないが, 図 4 の場合の同様の温度領域よりも温度依存性が見られてお り, 活性化エネルギーが分布しているような特性となって いる。この素子について, 図 7(a)で直線性が観測されてい る温度領域のいくつかの温度でエネルギー分布パラメータ $E_{t}$ を調べた。その結果を図 $7(\mathrm{~b})$ に示す。 $m$ と $1 / T$ はほぼ比 例しており， $m=T_{t} / T$ の関係を満足していることがわかる。 この近似直線の傾きから $T_{t}$ あるいは $E_{t}\left(=k T_{t}\right)$ を計算する ことができ， $E_{t}$ は約 $0.147 \mathrm{eV}$ と見積もられた。この值は同 図(a)で得られた電子伝導の活性化エネルギーにほぼ等し い。今のところまだ明確でないが, 指数関数的なエネルギ 一分布のパラメータが，電気伝導の活性化エネルギー（温 度依存性）をほぼ反映している可能性もあり，今後さらに 研究を進めたいと考えている。なお，実験結果に対して一 本の直線で近似したが，直線の外挿は 0 点を通らず， $1 / \mathrm{T}$ の小さい領域（300Kに近い領域）では実験結果の傾きが緩 くなっている。この結果は明確でないが, 単一のトラップ 分布パラメータで実験結果を表せないためであると考え る。

〈3.3〉 有機 EL 素子のキャリア伝導図 8 に ITO/TPD $(60 \mathrm{~nm}) / \mathrm{Alq}(60 \mathrm{~nm}) / \mathrm{LiF}(0.5 \mathrm{~nm}) / \mathrm{Al}$ の 2 層型有機 $\mathrm{EL}$ 素子における $J-V$ 特性の温度依存性を示す。前節で述べ たように Alq 層は TPD 層よりも抵抗が高くより多くの電圧 が Alq 層側に分配されており, 電流律速は主に Alq 層側で 行われているものと考えられる。その一方で, EL 素子にお いては注入されたホールと電子の再結合が支配的であるた め, Double Injection と再結合が関わる複雑な電気伝導によ つており,さまざまな構造での詳細な研究が必要であると 考えられる。

図 8 の- $V$ 特性は $223 \mathrm{~K}$ 以上と $173 \mathrm{~K}$ 以下の間で不連続 になっているように見える。 $223 \mathrm{~K}$ 以上の温度領域では, $J-V$ 特性は約 $10 \mathrm{~mA} / \mathrm{cm}^{2}$ 付近の電流領域から 2 から 4 桁にわた

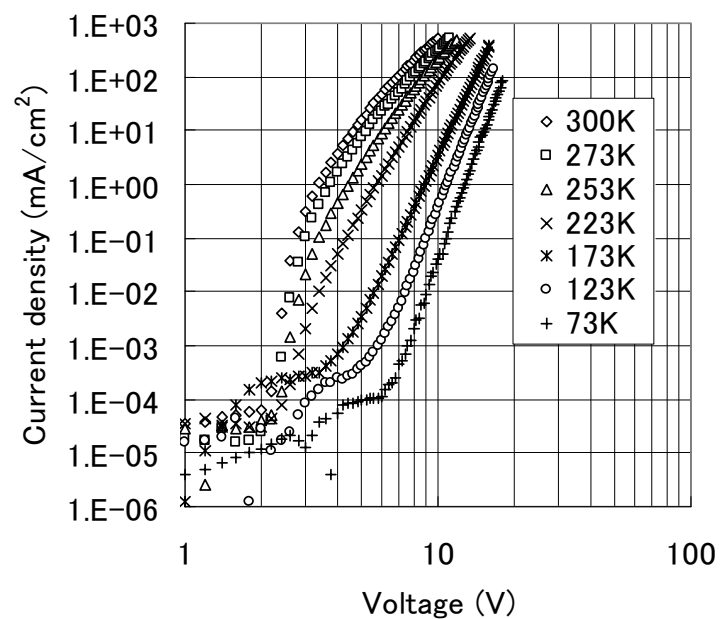

図 8 有機 $\mathrm{EL}$ 素子における $J-V$ 特性の温度依存性

Fig. 8. Temperature dependence of $J-V$ property in OLED.
って Alq 層でも観測された $(4)$ 式の $J \propto V^{m+1}$ 特性にほぼ一致 していた。ショットキー注入電流の(2)式にもフィッティン グを試みたが良い一致は得られなかった。したがって，こ の温度領域では指数関数的なエネルギー分布トラップを含 む SCLC 特性が支配的と考えられた。

図 8 の $173 \mathrm{~K}$ 以下の温度領域では, 電導電流は約 $10^{-3} \mathrm{~mA} / \mathrm{cm}^{2}$ 付近の電流領域からほぼ 5 桁にわたって $J \propto V^{m+1}$ 特性で表される直線的な増加を示した。Alq 単層素 子においても低温 $(73 \mathrm{~K})$ では同様な 5 桁にわたる直線的な 電流増加が観測されており，この温度領域においても Alq 層によって電流が律速されているものと考えられた。

図 9(a)に ITO/TPD $(60 \mathrm{~nm}) / \mathrm{Alq}(60 \mathrm{~nm}) / \mathrm{LiF}(0.5 \mathrm{~nm}) / \mathrm{Al} 2$ 層型有機 EL 素子における定電圧駆動時 $(10 \mathrm{~V})$ の電導電流 の温度特性を示す。電導電流は図のアレニウスプロットの ように約 $1 / T$ が $0.006 \mathrm{~K}^{-1}$ よりも小さい領域（約 $170 \mathrm{~K}$ 以上 の温度領域）で直線的に振る舞い， $0.185 \mathrm{eV}$ の活性化エネ ルギーが得られた。また図 9(a)の約 $150 \mathrm{~K}$ 以下の温度領域

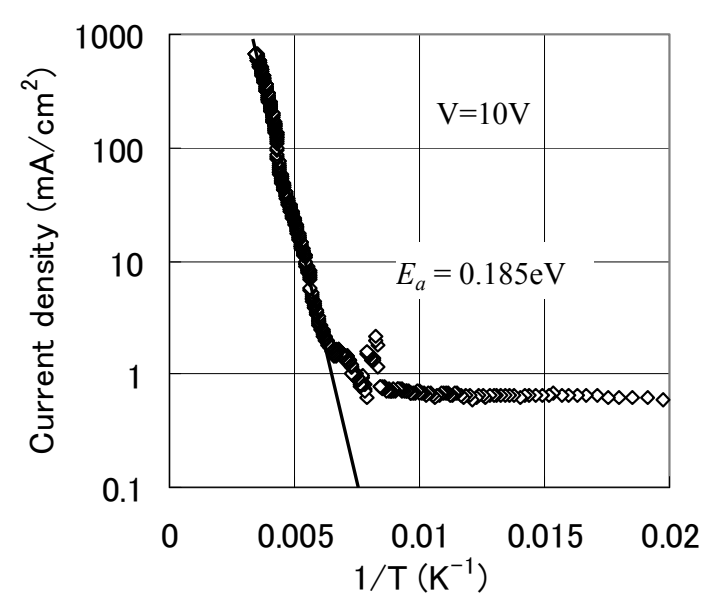

(a) Thermal dependence of conduction current with constant voltage

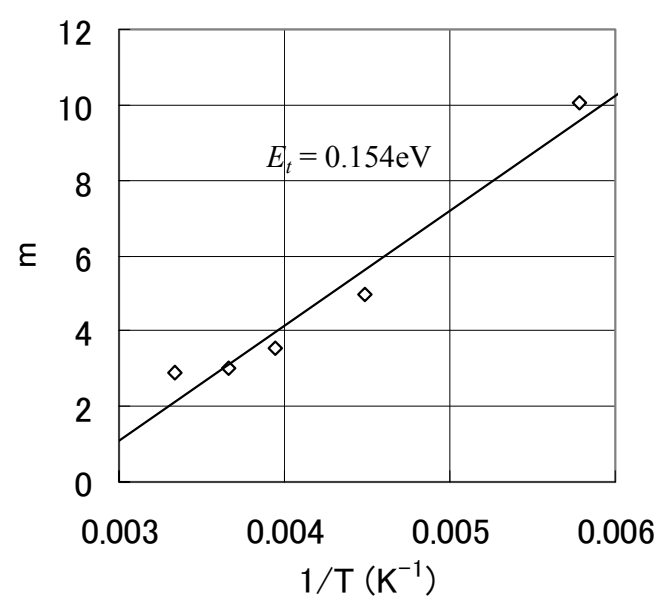

(b) Thermal property of $\mathrm{m}$ in Eq. (4)

困 9 有機 EL 素子における電子伝導の温度特性

Fig. 9. Thermal property of current conduction in OLED. 
では，電導電流はほとんど温度依存性が観られなかった。 この特性は図 7(a)の温度特性と異なっているが，有機 EL 素子では TPD 層から Alq 層へもホールが多く注入されるた め, 同様な特性が得られなかったと考えられる。なお, 図 8 の $73 \mathrm{~K}$ の $J$ - $V$ 特性は, トンネル電流の $(3)$ 式には一致して いなかった。したがって，各温度での $J-V$ 特性については さらに詳細に調べる必要があると考える。

図 8 の $223 \mathrm{~K}$ 以上のいくつかの温度で, 電流が $J \propto V^{m+1}$ 特性に近似できる領域におけるエネルギー分布パラメータ $E_{t}$ を求めた。その結果を図 $9(\mathrm{~b})$ に示す。図 $7(\mathrm{~b})$ と同様にこ の場合も $m$ と $1 / T$ はほぼ比例しており, この傾きから $T_{t}$ あるいは $E_{t}$ が求められ， $E_{t}$ は約 $0.154 \mathrm{eV}$ であった。この值 は図 9(a)で見積もられた活性化エネルギーよりも小さい值 となった。この違いは, 単層膜に対する SCLC 理論を TPD 層と Alq 層からなる 2 層 $\mathrm{EL}$ 素子にそのまま適用すること で生じている可能性が考えられた。また, 前述のように EL 素子においてはホールと電子の Double Injection と再結合 が支配的であるため電気伝導が複雑であり, 単純な SCLC 理論で説明できないことも原因として考えられた。さらに, 実際の Alq 膜中に存在するトラップの分布についても不明 な点が多いため, より詳しく研究を進める予定である。

有機 EL 素子の温度依存性は実際の利用においては極め て重要であり, 電気伝導機構を詳細に明らかにすることは, 極めて意義があるものと考える。

\section{4. まとめ}

本研究では TPD, Alq をそれぞれ用いた単電荷素子にお ける電気伝導の温度特性から，2 層型有機 EL 素子のキャリ ア挙動と温度依存性の相関について考察した。TPD 単層膜 素子では, $100 \mathrm{~mA} / \mathrm{cm}^{2}$ 以上の領域において, $300 \mathrm{~K}$ 付近で の電流はほぼ空間電荷に起因したバルク律速の電流とな り, $10 \mathrm{~mA} / \mathrm{cm}^{2}$ 以下の電流領域では熱活性型の電荷注入が支 配的と考えられた。また, $73 \mathrm{~K}$ 付近の温度領域では, 広い 電流領域にわたりトンネル注入型の界面律速電流が支配的 と考えられた。このことから, 温度によって電導機構が大 きく変化することが明らかになり, 有機 EL 素子が温度依存 性を示す一因と考えられた。一方, Alq を用いた単層膜素子 や Alq 層膜が含まれる 2 層型有機 $\mathrm{EL}$ 素子においては, 広 い電流領域で $J \propto V^{m+1}$ 特性に一致する特性が観測された。 したがって, トラップ存在下の空間電荷によるバルク電流 が支配的と推定された。さらに本論文では，実験によって 得られた $J-V$ 特性が, Alq 膜中に指数関数的にエネルギー分 布するトラップが存在すると仮定して解析した空間電荷制 限電流特性にほぼ一致することがわかった。つまり有機 EL 素子の電気伝導は Alq 膜中のトラップに影響を受けた電子 伝導が支配的であると考えられ，その温度依存性もトラッ プの影響を大きく受けると推定された。したがって，今後 熱的に安定な有機 EL 素子の開発を進める上で,

（1）トラップが形成されにくい材料。

（2）トラップが形成されにくい薄膜化技術。
（3）電荷注入の温度依存性が小さいデバイス。 などの開発が重要と考えられた。

一方で, Alq 膜中のトラップが実際にどのように分布して いるのかなど不明な点も多いため, 今後さらに研究を進め る予定である。

(平成 18 年 7 月 5 日受付, 平成 19 年 4 月 10 日再受付)

\section{文献}

(1) C. W. Tang and S. A. VanSlyke : Appl..Phys. Lett., Vol.51, p.913 (1987)

(2) C. Adachi, S. Tokito, T. Tsutsui, and S. Saito : Jpn. J. Appl. Phys., Vol.27, p.L269 (1988)

(3) C. Adachi, S. Tokito, T. Tsutsui, and S. Saito : Jpn. J. Appl. Phys., Vol.27, p.L713 (1988)

(4) C. Adachi, T. Tsutsui, and S. Saito : Jpn. J. Appl. Phys., Vol.55, p.1489 (1989)

(5) C. Adachi, T. Tsutsui, and S. Saito : Jpn. J. Appl. Phys., Vol.57, p.531 (1990)

(6) T. Wakimoto, Y. Fukuda, K. Nagayama, A. Yokoi, H. Nakada, and M. Tsuchida : IEEE Trans. Electron Devices, Vol.44, p.1245 (1997)

(7) P. E. Burrows, V. Bulovic, S. R. Forrest, L. S. Sapochak, D. M. McCarty, and M. E. Thompson : Appl. Phys. Lett., Vol.65, p.2922 (1994)

(8) M. A. Baldo, D. F. O’Brien, Y. You, A. Shoustikov, S. Sibley, M. E. Tompson, and S. R. Forrest : Nature, Vol.395, p.151 (1998)

(9) B. G. Streetman and S. Banerjee : Solid State Electronic Devices, Prentice Hall (2000)

(10) J. G. Simmons : J. Appl. Phys., Vol.34, p.1793 (1963) A. Rose : Phys. Rev., Vol.97, p.1538 (1954)

(11) Murray A. Lampert, and Peter Mark : Currents Injection in Solids, Academic Press (1970)

(12) P. E. Burrows and S. R. Forrest : Appl. Phys. Lett., Vol.64, p.2285 (1994)

(13) P. E. Burrows, Z. Shen, V. Bulovic, D. M. McCarty, S. R. Forrest, J. A. Cronin, and M. E. Thompson : J. Appl. Phys., Vol.79, p.7991 (1996)

(14) Z. Shen, P. E. Burrows, V. Bulovic, D. M. McCarty, M. E. Thompson, and S. R. Forrest : Jpn. J. Appl. Phys., Vol.35, p.L401 (1996)

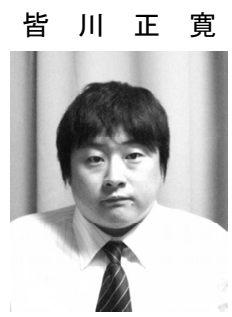

（学生員） 1974 年 12 月生まれ。1998 年 3 月 新潟大学工学部電気電子工学科卒業。2 000 年 3 月新潟大学修士号 (工学) 取得。同年 4 月（株） 沖データに入社。2 2001 年 1 月日本精機（株） に入社, 現在に至る。この間, 2003 年山形大 学工学部共同研究員, 2004 年 4 月新潟大学大 学院自然科学研究科博士後期課程入学。2007 年 3 月博士号 (工学) 取得。有機 EL, 有機 FET を主とした新規電子デバイスの研究開発に従事。

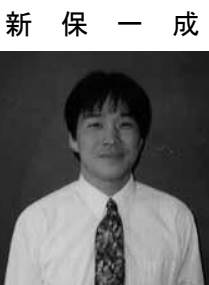

（正員） 1967 年 6 月生まれ。1995 年 3 月新 潟大学大学院自然科学研究科博士課程修了。同 年 4 月同大学大学院助手, 1997 年 4 月同大学 工学部講師, 1998 年 2 月同大学工学部助教授, 2007 年 4 月同大学工学部准教授, 現在に至る。 博士 (工学)。機能性有機薄膜の研究に従事。 応用物理学会, 電子情報通信学会会員。 


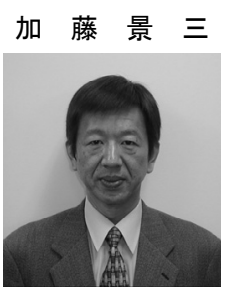
会員。
金 子 双 男 (上級会員) 1950 年 4 月生まれ。 1974 年 3 月 新潟大学大学院工学研究科修士課程修了。同年 4 月東京工業大学工学部助手。1 1981 年 4 月新潟 大学工学部助教授, 1992 年 4 月同教授, 現在 に至る。この間, 1986 年 3 月〜 1989 年 1 月 MIT 客員研究員。工学博士。電気電子材料, 有 機薄膜の研究に従事。応用物理学会, 電子情報 通信学会, 日本液晶学会会員。 